УДК 94(4/9)

DOI https://doi.org/10.32838/2663-5984/2021/2.5

\title{
Миронюк О.Ю.
}

Київський національний університет імені Тараса Шевченка

\section{ДІЯЛЬНІСТЬ УКРАЇНСЬКОЇ ГРОМАДИ В ЛАТВІЇ}

Дослідження присвячено всебічному аналізу життя украӥнської діаспори в Латвї. У иій краӥні украйнська громада, як і в інших краӥнах колишнього Радянського Союзу, почала активну діяльність у кінці 1980-х років. Саме з того часу почали утворюватися громадські організаиіï, які й дотепер є важливими осередками намої діаспори. Вони ведуть потужну громадську та культурно-просвітницьку роботу. Уже досить довгий час громади поширюють та популяризують наші культурні традииї. Етнічні українці на постійній основі допомагають своїй Батьківщині та підтримують позитивний імідж Украӥни в Свропі та світі. Також необхідно зауважити, що українські громади у Латвї активно впливають на прозоре висвітлення подій, ще відбуваються в Україні. Украӥнська громада в Латвї̈ збільшується з кожним днем, про це говорить і статистика, вказуючи на те, що зараз украйнці більш чисельні у крайні, ніж навіть росіяни. Але попри те, щьо діяльність українців у Латвії досить помітна, наші земляки у иій країні швидко асимілюються та втрачають свою украйнську самосвідомість. Зокрема, однією з причин иього є те, щзо у Латвійській Республічі дуже активною є російська діаспора, яка довгий час була чисельнішою, що призводило до того, що українці активно до неї приєднувалися. Також варто додати, щзо украйнська громада в Латвї надзвичайно розрізнена. Про це навіть йдеться на рівні крайни, оскільки неодноразово цей факт зауважував навіть президент держави у своїх інтерв'ю. Нині немає жодної трунтовної праиі, яка б досліджувала та порівнювала життя української громади в Латвії у сучасний період. Отже, саме систематизування та аналіз інформаиї з приводу діяльності украӥнської громади в Латвї є надзвичайно актуальними, адже українська громада за кордоном є важливим рушієм української культури та популяризачії наших традиџій.

Ключові слова: громадська організачія, діаспора, українці, українська громада, культура.

Постановка проблеми. У зв'язку з подіями, які відбуваються на Сході України, велика кількість нашого населення приймає рішення змінити країну свого проживання. Зокрема, досить популярним напрямком еміграції для українців $є$ країни Балтії. Із кожним роком українська громада в Латвійській Республіці збільшується. Але, прибуваючі у нову країну, деякі українці намагаються зберігати та популяризувати свою культуру, інші ж асимілюються 3 місцевим етносом чи російським, приєднуючись до більш активних громад.

Аналіз останніх досліджень і публікацій. Тема діяльності закордонних українців, зокрема в країнах Балтії, найкраще висвітлена у вітчизняній літературі. Дослідження громадсько-політичної діяльності українців почалося ще 3 початку утворення організацій у цих країнах, тобто 3 кінця 1980-х років. Але переважно вони є складовою частиною праць про українців у світі, як, наприклад, у роботі В.П. Трощинського та А.А. Шевченко, де українцям Латвії виокремлено свій розділ. Важливим $є$ також розуміння статистичних даних, розроблених нашими науковцями, гарним сучасним дослідженням на цю тему $€$ робота A.I. Зубик на здобуття ступеня кандидата географічних наук та багато інших. Цікавою для аналізу є монографія А.В. Зав'ялова, яка присвячена соціальній адаптації українців за кордоном, зокрема й у Латвійській Республіці. Важливим джерелом для дослідження закордонних українців $є$ огляд офіційних сайтів громадських організацій, які діють у Латвії, та Інтернет-ресурсів, які висвітлюють новини нашої діаспори. На даному етапі вони найбільш активні у соціальних мережах. Джерельна база подальшого дослідження складається зі свідчень учасників громадських і культурних об'єднань Латвії, звітної роботи громадських організацій цих країн і Світового конгресу українців.

Постановка завдання. Мета статті полягає у тому, щоб охарактеризувати громадську та культуротворчу діяльність української діаспори в Латвії шляхом проведення системного аналізу всіх доступних шарів матеріалу.

Виклад основного матеріалу дослідження. У Латвійській Республіці українська діаспора 3'явилася лише на початку XX ст. До цього часу українців тут мешкало небагато та організованої 
спільноти вони не утворювали. Наприклад, у Ризі наприкінці XIX ст. існувала невелика колонія, яка складалася зі службовців, робітників і студентів політехнічного інституту. Перші спроби об'єднати українську спільноту робилися ще 3 початку 1900-х років. І лише в 1911 р. було створено перше українське земляцьке об'єднання - «Громада», що будувало свою діяльність на принципах взаємодопомоги та збереження українцями своєї національної ідентичності. За мету об'єднання мало згуртувати навколо себе українські сили Латвії, привернути увагу місцевої латиської та російської інтелігенції до українських проблем. Його діяльність висвітлювалася газетою Dzimtenes Vestnesis на постійній основі [2, с. 60].

Необхідно зазначити, що про заснування першого товариства українців дізналися не так давно. Інформацію було знайдено в архівних документах Українського інформаційного центру при Латвійській академічній бібліотеці. Про це зазначив тогочасний керівник Об'єднання українців Латвії Володимир Луговський в інтерв'ю «Радіо Свобода» у 2006 р.: «Українці живуть понад 160 років на латвійській землі. Чому ж святкуємо 95-річчя? Ми замовили в архів і запит про те, коли ж офіційно була заснована перша українська громада в Латвії. Нам знайшли, що в 1911 році вперше в Латвії була заснована українська громада, вона так і називалася «Громада», в якій був і театр, і каса взаємодопомоги. Їх тоді було 1844 українці» [7].

Уже під час Першої світової війни діяльність української громадськості в країні припинилася. Деякі українці приєдналися до Латиських стрільців (латис. Latviešu strēlnieki), а деякі - до 12-ї армії Російської імперії, штаб якої містився в Ризі i де були створені українські організації, український клуб, обрано виконавчу раду армії. А в період з 1917 по 1918 р. у Ризі видавалася газета «Український голос» - орган Української військової виконавчої ради Північно-Західного фронту. У 1918 р., коли Латвією була проголошена незалежність, були встановлені дипломатичні відносини з Українською Народною Республікою, що підтримувалися до 1921 р. Згодом Латвія визнала Українську Радянську Соціалістичну Республіку, що допомогло розв'язувати питання з біженцями та оптантами. Саме у міжвоєнний період почала зростати кількість українців у Латвії. Українці проживали переважно в містах. Більшість із них переїхала в Латвію саме через Першу світову війну та отримувала місцеве громадянство через одруження. Загалом такі громадяни швидко інте- грувалися у латвійське суспільство і не зазнавали труднощів із латиською мовою [2, с. 60].

Відродження української громадськості було відчутно у 1930-ті роки. Зокрема, у 1932 р. було утворено Латвійсько-українське товариство. Воно мало тісні контакти з організаціями Львова, Литовським українським товариством, організовували численні культурні заходи: літературно-музичні вечори, лекції, концерти, театральні вистави. Станом на 1936 р. Товариство нараховувало понад 70 членів. А в 1934 р. було відкрито українську бібліотеку, у 1935 р. - український хор [11, с. 289]. Але вже у 1940 р., 3 приходом радянської влади, усі громадські організації були ліквідовані. Багато активістів були арештовані та депортовані в радянські трудові табори. У 1943 р., коли нацистська Німеччина окупувала Латвію, спостерігалося збільшення чисельності українців. За даними перепису населення 1943 р., проведеного нацистською Німеччиною, у Латвії проживало 11,5 тис українців. Були враховані трудові в'язні з України й військовополонені Червоної Армії. Частина українців під час війни приєдналася до Латиського легіону, частина - до армії нацистської Німеччини, але також велика частина перебувала в партизанських загонах та у Червоній Армії. Більшість місцевих українців після закінчення Другої світової війни емігрувала в західні країни [2, с. 61]. Загалом після закінчення Другої світової війни почався основний потік міграції етнічних українців до Латвії. Українців сюди направляли як молодих фахівців для розвитку виробництва, на будівництво промислових об'єктів, деякі прибули до Латвії на сезонні роботи та вирішили залишитися. Також велику частину становили військові пенсіонери колишньої Радянської Армії.

У Латвійській РСР, як і в інших радянських республіках, громадських українських організацій не існувало довгий час [2, с. 61]. Це негативно позначилося на національно-культурному розвитку українців, що зумовлювало швидку втрату ними своєї етнічності, зокрема мови.

Але ситуація почала змінюватися у кінці 1980-х років. У даний період для більшості країн пострадянського простору була досить характерною тенденція зростання активності націоналістичних рухів, оскільки на часі були питання перебудови тогочасного ладу та відновлення незалежності. Ці питання були актуальні й для Латвії. Отже, у країні почала створюватися ціла низка товариств національних меншин. Одними 3 перших свою етнічну організацію створили саме українці. Таким чином, 1988 р. почалась історія 
сучасної української громади зі створення культурно-просвітнього товариства «Дніпро». За свою мету вони поставили збереження української мови, традицій та культури нашого народу, задоволення культурно-освітніх потреб українців у Латвійській Республіці. Із 1989 р. в «Дніпрі» активно діє ансамбль української народної пісні 3 однойменною назвою. Також при товаристві відкрили літературний клуб української поезії й прози та клуб пенсіонерів «Берегиня». Але офіційно зареєстровано культурно-просвітнє товариство «Дніпро» було лише у 1991 p.

Певно, найважливішим моментом в історії української громади у Латвії став розпад Радянського Союзу та відновлення Латвією своєї незалежності, тоді становище української спільноти у цій республіці зазнало суттєвих змін. Уперше за багато десятиліть з'явилися умови для поступового налагодження організованого національного-культурного життя - створення українських освітніх закладів, центрів культури та преси. Водночас українці постали перед низкою складних і нових для них проблем. Однією 3 найгостріших була проблема набуття латвійського громадянства, оскільки в липні 1990 р. Сеймом було прийнято «Закон про громадянство Латвійської Республіки», який передбачав, що громадянство можуть набути лише ті особи, які мають статус постійних мешканців і які після 4 травня 1990 р. не менше п'яти років постійно проживали на території Латвії та склали досить жорсткі іспити зі знання латиської мови, основних положень Конституції, конституційного Закону «Права та обов'язки людини та громадянина», державного гімну та історії цієї країни. Саме через це українська спільнота опинилася у надзвичайно скрутному становищі [11, с. 290], оскільки це було під силу не всім. Загалом треба зазначити, що українські громадські об'єднання Латвії діють на основі Закону Латвійської Республіки «Про вільний розвиток національних та етнічних груп Латвії та їх права на культурну автономію» (ухвалений 19 березня 1991 р.). Він гарантує всім національним та етнічним групам рівні права, що відповідають міжнародним нормам прав людини. У цій країні особи, які належать до національних меншин, мають право зберігати та розвивати свою мову та етнічно-культурну ідентичність, а держава їм у цьому допомагає, а також Закону «Права та обов'язки людини і громадянина (ухвалений 10 грудня 1991 р.). Національно-культурні аспекти життєдіяльності української громади тісно пов'язані також із законодавчими актами про функціонування державної мови та освіти. Хоча, згідно з чинним законодавством, до національних меншин належать усі постійні жителі Латвії нелатиської національності, але ухвалені впродовж 1992-1994 рр. інші законодавчі акти значною мірою обмежують права негромадян Латвії. Це суттєво впливає на розв'язання проблем етнічних меншин цієї країни, зокрема й української. За інформацією Департаменту громадянства та імміграції Латвії, станом на 10 грудня 1996 р. лише 6\% українців, що проживають тут, набули громадянства цієї країни [11, с. 292]. Ще одна проблема стояла перед частиною українціввійськовиків, звільнених на пенсію з Радянської Армії, та членів їхніх родин - вимога залишити, згідно з угодами між Росією і Латвійською Республікою, територію цієї країни. Деякі із цієї категорії осіб уже повернулися до України, інші виїхали в Росію, де їм зобов'язалися надати житло. Очевидно, що саме ці чинники зумовили процес рееміграції. Таким чином, до 1995 р. чисельність українців Латвії зменшилася більше ніж на 25 тис осіб. Отже, для українців Латвії сальдо міграції було негативним, але водночас для України сальдо міграції було позитивним [11, с. 290].

Більшість дослідників уважає, що українці Латвії слабо інтегровані у середовище титульного етносу країни. Однією 3 причин цього є слабке володіння латиською мовою. Також варто зазначити, що більшість українських дітей нині навчається в російськомовних школах або латиських i російських школах із двома потоками, незважаючи на те що у Ризі з 1990 р. діє українська середня школа. I хоча уряд України надав Ризькій державній українській школі відчутну фінансову допомогу, це все ще недостатньо для ії активного розвитку [11, с. 291].

Але необхідно зазначити, що деякі дослідники вбачають у національній політиці Латвії певні обмеження в праві на отримання освіти рідною мовою. Наприклад, прийнятими в Латвії 22 січня 2004 р. поправками до Закону «Про освіту» 1998 р., що з вересня 2004 р. в старших класах середніх шкіл Латвії, в яких реалізуються програми освіти національних меншин, навчання має здійснюватися державною (латиською) мовою. У Латвії на парламентських виборах 1992 р. виборче право мали лише громадяни, які отримали громадянство Латвії до 14 червня 1940 р., а також їхні нащадки. Тобто майже $30 \%$ населення країни (російськомовна частина) не в змозі були проголосувати [8, с. 100]. На думку Свгена Ткаченка, мовна політика країни має дискриміна- 
ційний характер. Дослідник зазначає, що мовне законодавство продемонструвало тенденцію до встановлення обмежень щодо використання мов меншин та високі вимоги обов'язкового оволодіння державною мовою [10, с. 189]. Отже, навіть існуюча українська школа у Ризі не працює у повну силу. У ній навчання ведеться латиською мовою і лише факультативно - українською. За законом у нелатиських навчальних закладах навчання ведеться на $60 \%$ латиською мовою, а на $40 \%$ - мовою нацменшини [12]. Але більшість дітей представників української діаспори вчилася переважно в російськомовних школах, а вдома українську мову підтримували не всі [5].

Згідно 3 результатами перепису населення 2000 р., у країні проживали 63644 українця, 3 яких 31798 - чоловіки та 31846 - жінки, що становить $49,96 \%$ та 50,04\% відповідно, за чисельністю це четверта етнічна група після латишів, росіян та білорусів. За 1989-2000 рр. чисельність українців зменшилася на 30,9\%. Близько половини українців проживає у Ризі - 49,7\%, менше у містах Лієпая (7,9\%), Даугавпілс (3,9\%), Вентспілс $(3,7 \%)$, Слгава $(3,11 \%)$ та Юрмала $(2,6 \%)$. Незважаючи на збільшення чисельності українців через прибуття трудових мігрантів та тих, хто переїхав до Латвії на постійне місце проживання, чисельність українців зменшується. Причинами цих процесів є русифікація українців, слабка інтеграція в латвійське суспільство, проблема набуття латвійського громадянства, зміна етнічної приналежності [4, с. 81$]$.

Довгий час не вдавалося об'єднати, скоординувати та налагодити роботу товариств Латвії, які залишалися роз'єднаними. Навіть незважаючи на спроби об'єднати їх в одну організацію зі спільним вектором розвитку. Але в 2005 р. після створення «Об'єднання українських товариств Латвії» під керівництвом Володимира Луговського ситуація змінилася на краще. Тоді в одну спільну громадську організацію об'єдналися п'ятнадцять товариств, а також юридичні одиниці. Уже наступного року «Об'єднання українських товариств Латвії» вперше завітало до Львівської політехніки 3 великою делегацією. А вже в 2011 р. на офіційне сторіччя діаспори «Об'єднання українських товариств Латвії» вдруге завітало до МІОКу. Саме тоді діяльність української громади Латвії стала помітнішою на міжнародному рівні. 26 березня 2011 p. в Ризі відбулася міжнародна науково-практична конференція, присвячена сторіччю діаспори, яка підвела підсумки діяльності української громади Латвії й намітила завдання, спрямовані на іiі роз- виток на майбутнє. Одним із важливих завдань Об'єднання є залучення молоді до участі в громадському житті Латвії. У травні 2012 р. відбулася презентація нового українського молодіжного ансамблю «Веснянка». Громада активно влаштовує різні святкування, на яких часто присутні не лише етнічні українці, оскільки робота діаспори викликає зацікавленість і в представників інших національностей. Сьогодні ще $є$ актуальною проблема громадянства серед української громади через погане володіння латиською мовою старшим поколінням та неактивну громадянську позицію у цілому [1].

У серпні 2012 р. була створена громадська організація «Конгрес українців Латвії», яка, згідно зі своїм статутом, здійснює діяльність на основі християнських традицій, організує та підтримує ініціативи українських громад із проведення культурних заходів. Останні спрямовані на виховання почуття національної самосвідомості та патріотизму, гордості за Україну та Латвію, на формування злагоди та єдності між народами, на сприяння вивченню та збереженню народних традицій. Із 7 вересня 2013 р. «Конгрес українців Латвії» став крайовою організацією «Світового конгресу українців». Завдяки підтримці «Конгресу українців Латвії» місцеві українці мають можливість слухати проповіді та молитися рідною мовою. У Ризі, у каплиці церкви Скорботної Божої Матері, є парафія Української грекокатолицької церкви, а в грудні 2012 р. до Латвії 3 України прибув новий ієрей о. Роман Сапужак, щоб надалі постійно бути разом із місцевими українськими греко-католиками [1, с. 309]. Але не всі мають змогу відвідувати цю церкву, особливо жителі інших міст Латвії, тому великий відсоток українців відвідує церкви Московського патріархату, які є чисельнішими у країні. Ці аспекти призводять до того, що досить велика частина українців, що проживає у Латвії, перебуває під впливом проросійського світосприйняття.

Необхідно зауважити, що цього питання торкався й президент Латвії Егілс Левітс у своєму інтерв'ю. Він зазначив: «Що стосується діаспори України в Латвії, звісно, я знаю про іiї існування. Але також знаю про такий аспект... не хочу вживати слово «розрізнена»... Скажімо так - українська діаспора розділена на два крила. Одне проукраїнське, а інше - більше налаштоване на російське світосприйняття» [6].

У контексті останніх подій необхідно зазначити, що в країнах Балтії етнічне населення та влада відносяться до українців по-різному. 
Однією з причин упередженості може слугувати різке зростання мігрантів до цих країн, який став особливо активним після Революції гідності та початку АТО. Говорячи про Латвію, то тут ставлення до українців в попередні роки було досить позитивним. Причиною цього було те, що ще 3 кінця 1980-х українці були першими з нацменшин, які почали підтримувати рух латишів за повернення незалежності. Як зазначає Віктор Стефанович, голова правління Союзу українців Латвії, «якщо скажеш, що ти українець, відношення змінюється, навіть якщо скажеш це російською» [6].

Також у ще одному своєму інтерв'ю президент країни Левітс Егілс зазначає: «Останніми роками в Латвії присутня значна кількість гостьових українських робітників, що доповнює нашу робочу силу. Це також дуже вагомо, оскільки в нас у цій сфері є свої недоліки. А таким чином вони усуваються, що допомагає нашій економіці» [9]. Звісно, є велика частина кваліфікованих кадрів, які мають дозволи на роботу за кордоном та працюють офіційно. Але, з іншого боку, $є$ й чисельний прошарок тих, хто працює без необхідних дозволів. Як зазначає латвійське видання Skaties, громадяни України становлять найбільшу частку іноземців на ринку праці - трохи більше половини всіх працівників. Найбільшими групами нелегально зайнятих були громадяни саме України, Молдови та Росії [13].

Висновки. Отже, незважаючи на активну діяльність української діаспори у Латвії, у цій країні $є$ надзвичайно великий російський вплив. Основною причиною цього є відсутність достатнього фінансування та допомоги від України, а також складність організації яскравих та культурних подій. Важливим $є$ той факт, що на відміну від інших балтійських країн українці тут починають уважати себе носіями російської культури, а не української чи навіть латиської. Саме тому дослідження даного питання $є$ нагальним та актуальним.

\section{Список літератури:}

1. Бєлинцева Л. Сила в єдності : збірник матеріалів четвертої Міжнародної науково-практичної конференції. Львів : Львівська політехніка, 2013. 630 с.

2. Завьялов А.В. Социальная адаптация украинских иммигрантов : монография. Иркутск : ИГУ, 2017. 179 c.

3. Звіт Конгресу українців Латвії (серпень 2012 р. - липень 2013 р.). Річні загальні збори СКУ. Збірник звітів. Львів. 2013. 352 с.

4. Зубик А.І. Сучасна українська діаспора: розселення, соціодемографічні процеси : дис. ... канд. геогр. наук : 11.00.02. Львів, 2016. 340 с.

5. Кабачій Р. Українці у Латвії. Розмова з Віктором Стефановичем. Наше слово. 2014. URL: https://www.nasze-slowo.pl/ukrayintsi-u-latviyi/ (дата звернення: 05.03.2021).

6. Кудрін О. Егілс Левітс, президент Латвії. УКРІНФОРМ - Мультимедійна платформа іномовлення України. 2019. URL: https://www.ukrinform.ua/rubric-polytics/2796509-egils-levits-prezident-latvii.html (дата звернення: 23.12.2019).

7. Латвійці відзначили 95-річчя першої української громади в Латвії. Радіо Свобода. 2006. URL: https://www.radiosvoboda.org/a/953699.html. (дата звернення: 05.03.2021).

8. Обзор конституционных новостей. Конституцчионное право: Восточноевропейское обозрение. 1998. № 3(24). $101 \mathrm{c}$.

9. Президент Латвії: українські «гостьові робітники» сприяють латвійській економіці. УКРІНФОРМ - Мультимедійна платформа іномовлення Украӥни. 2019. URL: https://www.ukrinform.ua/rubricdiaspora/2796870-prezident-latvii-ukrainski-gostovi-robitniki-spriaut-latvijskij-ekonomici.html (дата звернення: 05.03.2021).

10. Ткаченко Є.В. Правовий захист прав етнічних та мовних меншин : навчальний посібник. Київ : ФОП Голембовська О.О., 2018. 315 с.

11. Трощинський В.П., Шевченко А.А. Українці у світі. Київ : Альтернативи, 1999. 352 с.

12. Українці у Латвійській Республіці. Посольство України в Латвійській Республіці. Офіційна сторінка. URL: https://atvia.mfa.gov.ua/ua/ukraine-lv/ukrainians-in-lv (дата звернення: 10.12.2018).

13. Skaties. Pilna spektra ziņu un izklaides portāls. 2019. URL: https://skaties.lv/zinas/bizness/ekonomika/ latvija-pern-vislielako-risku-nelegalas-nodarbinatibas-joma-veidoja-moldovas-un-ukrainas-pilsoni/ (дата звернення: 05.03.2021).

\section{Myroniuk O.Yu. ACTIVITIES OF THE UKRAINIAN COMMUNITY IN LATVIA}

The study is devoted to a comprehensive analysis of the life of the Ukrainian diaspora in Latvia. The Ukrainian community in this country has deep historical roots, but as in other countries of the former Soviet Union, it became more active in the late 1980s. From that time public organizations began to be formed, which 
are still important centers of our diaspora. They conduct powerful public and cultural-educational work. They have been spreading and popularizing our cultural traditions. Ethnic Ukrainians constantly help their homeland and maintain a positive image of Ukraine in Europe and in the world. It should also be noted that Ukrainian communities in Latvia actively influence the transparent coverage of events in Ukraine. At the moment, the Ukrainian community in Latvia is growing every day, according to statistics, indicating that Ukrainians are now more numerous in the country than even Russians.

But despite the fact that the work of the Ukrainian community in Latvia is quite noticeable, they quickly assimilate and lose their Ukrainian identity in this country. In particular, one of the reasons the integration of newly arrived Ukrainians into Russian community, that was for the long time larger in this country. It should also be added that the Ukrainian community in Latvia is extremely diverse. This is even discussed at the national level, as even the country's president has repeatedly noted this in his interviews. But part of Ukrainians tries to popularize our culture, so this gives hope that the development of the Ukrainian community will be stronger. Currently, there is no single research that investigates and compares the life of the Ukrainian community in Latvia in the modern period. Thus, the systematization and analysis of information about the activities of the Ukrainian community in Latvia are incredibly relevant. After all, the Ukrainian community abroad is an important mover for Ukrainian culture and the promotion of our traditions in the world.

Key words: public organization, diaspora, Ukrainians, Ukrainian community, culture. 